Article

\title{
Human Lysozyme Synergistically Enhances Bactericidal Dynamics and Lowers the Resistant Mutant Prevention Concentration for Metronidazole to Helicobacter pylori by Increasing Cell Permeability
}

\author{
Xiaolin Zhang ${ }^{1, *}$, Anmin Jiang ${ }^{2}$, Hao Yu ${ }^{1}$, Youyi Xiong ${ }^{1}$, Guoliang Zhou ${ }^{1}$, Meisong Qin ${ }^{1}$, \\ Jinfeng Dou ${ }^{1}$ and Jianfei Wang ${ }^{1,3, *}$ \\ 1 The Department of Pharmacy, Food and Drug School, Anhui Science and Technology University, \\ Fengyang 233100, China; yuh@ahstu.edu.cn (H.Y.); xiongyy@ahstu.edu.cn (Y.X.); \\ zhougl@ahstu.edu.cn (G.Z.); qinms@ahstu.edu.cn (M.Q.); doujf@ahstu.edu.cn (J.D.) \\ 2 The School of Life Science, University of Science and Technology of China, Hefei 230032, China; \\ SA12226011@mail.ustu.edu.cn \\ 3 The Ministry of Agriculture Key Laboratory of Microbial Organic Fertilizer, Bengbu 233030, China \\ * Correspondence: zhangxiaolin8@126.com (X.Z.); wangjf007@ahstu.edu.cn (J.W.); \\ Tel.: +86-550-673-2663 (X.Z.); +86-550-673-2007 (J.W.)
}

Academic Editor: Derek J. McPhee

Received: 5 September 2016; Accepted: 25 October 2016; Published: 28 October 2016

\begin{abstract}
Metronidazole (MNZ) is an effective agent that has been employed to eradicate Helicobacter pylori (H. pylori). The emergence of broad MNZ resistance in $H$. pylori has affected the efficacy of this therapeutic agent. The concentration of MNZ, especially the mutant prevention concentration (MPC), plays an important role in selecting or enriching resistant mutants and regulating therapeutic effects. A strategy to reduce the MPC that can not only effectively treat $H$. pylori but also prevent resistance mutations is needed. H. pylori is highly resistant to lysozyme. Lysozyme possesses a hydrolytic bacterial cell wall peptidoglycan and a cationic dependent mode. These effects can increase the permeability of bacterial cells and promote antibiotic absorption into bacterial cells. In this study, human lysozyme (hLYS) was used to probe its effects on the integrity of the H. pylori outer and inner membranes using as fluorescent probe hydrophobic 1-N-phenyl-naphthylamine (NPN) and the release of aspartate aminotransferase. Further studies using a propidium iodide staining method assessed whether hLYS could increase cell permeability and promote cell absorption. Finally, we determined the effects of hLYS on the bactericidal dynamics and MPC of MNZ in H. pylori. Our findings indicate that hLYS could dramatically increase cell permeability, reduce the MPC of MNZ for H. pylori, and enhance its bactericidal dynamic activity, demonstrating that hLYS could reduce the probability of MNZ inducing resistance mutations.
\end{abstract}

Keywords: H. pylori; metronidazole; human lysozyme; mutant prevention concentration; bactericidal dynamics

\section{Introduction}

H. pylori is a widespread human pathogen that colonizes over half of all individuals worldwide and up to $90 \%$ of people in some developing countries [1]. The stomachs of many individuals are infected by H. pylori, usually during childhood. H. pylori plays a decisive role in the development of peptic ulcers and chronic gastritis [2,3]. H. pylori is a carcinogen that is closely associated with the occurrence of gastric carcinoma and the development of mucosa-associated lymphoid tissue (MALT) lymphoma [4]. It has been established that the eradication of $H$. pylori would be the best strategy to 
prevent the gastrointestinal disorders of gastroduodenal ulcer and chronic gastritis $[2,3,5,6]$ and to reduce the incidence of gastric cancer [3,7]. Moreover, some reports indicate that the eradication of H. pylori would be beneficial for treatment of vitamin B12 deficiency, idiopathic thrombocytopenic purpura and unexplained iron deficiency anemia [8]. Additionally, it could reduce the emergence of ischemic heart disease, colorectal cancer and neurological disorders $[9,10]$. MNZ is an effective agent that can be used to eradicate H. pylori. However, the emergence of widespread MNZ resistance has affected the therapeutic outcome of $H$. pylori infections. It has been reported that resistance to MNZ may cause the cure efficiency using standard triple therapies to decrease by up to $50 \%$ [11]. To overcome $H$. pylori resistance, an increasing MNZ dose and an extended period of therapy may be used [12]. However, it has become evident that treatment using high concentrations of antibiotics can enhance the selection of resistant mutants $[13,14]$.

According to the proposed hypothesis for the mutant selection window (MSW), the antibiotic concentration plays an important role in selecting or enriching resistant mutants. As shown in Figure 1, the MSW represents an antibiotic concentration that is above the MIC and below the mutant prevention concentration (MPC) $[15,16]$. If the antibiotic concentration is below the MIC, the number of selected or enriched resistant mutants is reduced, but the antibiotic fails to eradicate the pathogenic bacteria and this leads to treatment failure. If an antibiotic concentration is within the MSW, it has a therapeutic effect, but it can enhance selection or enrichment of resistant mutants. Moreover, the MPC of an antibiotic for bacteria indicates the concentration where no resistant colony is found, even when $10^{10}$ bacteria are plated. If the MNZ concentration is above the MPC, not only can a full therapeutic H. pylori effect be obtained, but it can also reduce the selected or enriched resistant mutants. Therefore, an alternative strategy for reducing the MPC and narrowing the MSW of MNZ for H. pylori is needed to overcome the increasing amount of resistant mutants. Human lysozyme (hLYS) is a type of antimicrobial substance that is secreted from various cells and tissues [17-19]. Moreover, hLYS has muramidase activity that can catalyze the hydrolysis of bacterial cell wall peptidoglycans, including $\beta$-1,4-linked $N$-acetylmuramic acid (MurNAc) and $N$-acetyl glucosamine (GlucNAc) [20]. Additionally, some reports found that another effect occurs via muramidase-independent processes instead of a cationic dependent mode [21,22]. These effects can increase the permeability of bacterial cells and favor the entry of antibiotics into bacterial cells. Indeed, in this study, we found that the application of hLYS could dramatically reduce the concentration and time of the MNZ bactericidal kinetics, and alter the dimensions of the MSW by lowering the MPC. These findings indicate that hLYS has synergistic anti-H. pylori effects with MNZ and reduces the MPC, which is helps to reduce the incidence of resistance mutations.

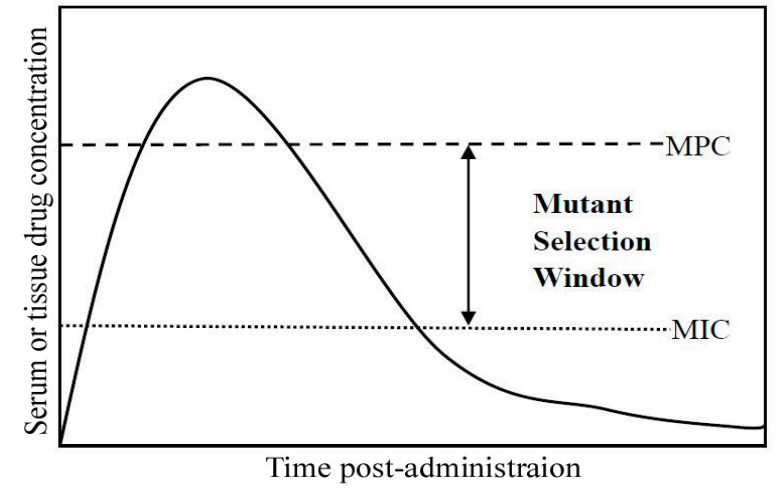

Figure 1. Pharmacodynamic characteristics of the mutant selection window. Drug concentrations indicated by the double-headed arrow between the mutant prevention concentration (MPC) and minimal inhibitory concentration (MIC) represent the mutant selection window. 


\section{Results}

\subsection{H. pylori Was Insensitive to Lysozyme}

The ATCC43504 strain of $H$. pylori was used to examine the sensitivity of lysozyme with 0.3 or $30 \mathrm{mg} / \mathrm{mL}$ of hLYS. Approximately $7.5 \times 10^{7}$ cells $/ \mathrm{mL}$ were treated with hLYS, and cell survival of $H$. pylori was determined after $0,2,4$, or $6 \mathrm{~h}$. We found that $H$. pylori was highly resistant to hLYS (Table 1). This finding was consistent with those of a previous study [23]. The gastric emptying time was about 4-6 h, and the concentration of hLYS in the stomach would decline with gastric emptying. Therefore, it was difficult to clear H. pylori with oral hLYS alone.

Table 1. Sensitivity of H. pylori to rhLYS.

\begin{tabular}{|c|c|c|c|c|}
\hline \multirow{3}{*}{ Time (h) } & \multicolumn{4}{|c|}{ Cell Survival } \\
\hline & \multicolumn{2}{|c|}{$0.3 \mathrm{mg} / \mathrm{mL}$ rhLYS } & \multicolumn{2}{|c|}{$30 \mathrm{mg} / \mathrm{mL}$ hLYS } \\
\hline & CFU/mL & $\%$ Survival & $\mathrm{CFU} / \mathrm{mL}$ & $\%$ Survival \\
\hline 0 & $7.5 \times 10^{7}$ & $100 \%$ & $7.5 \times 10^{7}$ & $100 \%$ \\
\hline 2 & $5.3 \times 10^{7}$ & $70.6 \%$ & $1.6 \times 10^{7}$ & $21.3 \%$ \\
\hline 4 & $1.2 \times 10^{7}$ & $16 \%$ & $4.8 \times 10^{6}$ & $6.4 \%$ \\
\hline 6 & $8.7 \times 10^{6}$ & $11.5 \%$ & $5.3 \times 10^{4}$ & $0.07 \%$ \\
\hline
\end{tabular}

H. pylori were treated with 0.3 or $30 \mathrm{mg} / \mathrm{mL}$ hLYS for $0,2,4$ or $6 \mathrm{~h}$. The number of surviving $H$. pylori cells was determined by cell colony counting.

\section{2. hLYS Promotes Increased Outer Membrane Penetration}

NPN has been used a hydrophobic fluorescent probe to investigate interactions between substances and the outer membrane of bacteria and to detect the permeabilization of the outer membrane [24,25]. The fluorescence of NPN is weaker in an aqueous solution and can become stronger after penetrating into the outer membrane hydrophobic environment. As shown in Figure 2, the fluorescence intensity was obviously enhanced when hLYS was added to the H. pylori suspension. These findings showed that penetration of the H. pylori outer membrane could be promoted by hLYS in a dose-dependent manner.

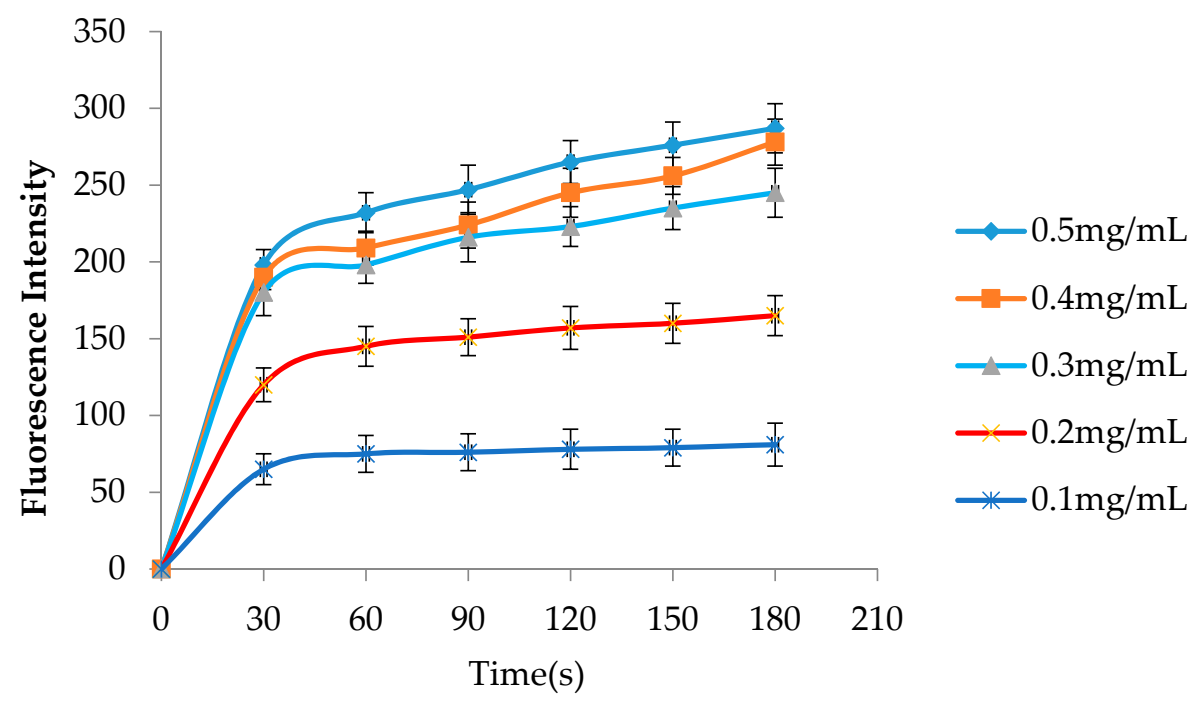

Figure 2. Effects of hLYS on permeability of the H. pylori outer membrane. The hLYS with different concentrations detect its ability of increasing membrane permeability through the change of the fluorescence intensity with time. 


\section{3. hLYS Can Disrupt the Integrity of the Inner Membrane}

To further probe the effects of hLYS on the integrity of the $H$. pylori inner membrane, an extracellular AspAT activity assay was used. Extracellular AspAT activity could increase as a consequence of enzyme release from the cytoplasm when the $H$. pylori inner membrane becomes damaged or destabilized by hLYS. The finding also showed that hLYS could induce changes in the H. pylori inner membrane integrity and promote the permeability of AspAT, which was indicated by a marked reduction in absorbance at $340 \mathrm{~nm}$ when $\mathrm{NADH}$ was oxidized to NAD+, and a marked increase in extracellular AspAT activity resulting from aspartate aminotransferase release from the cytoplasm (Figure 3).

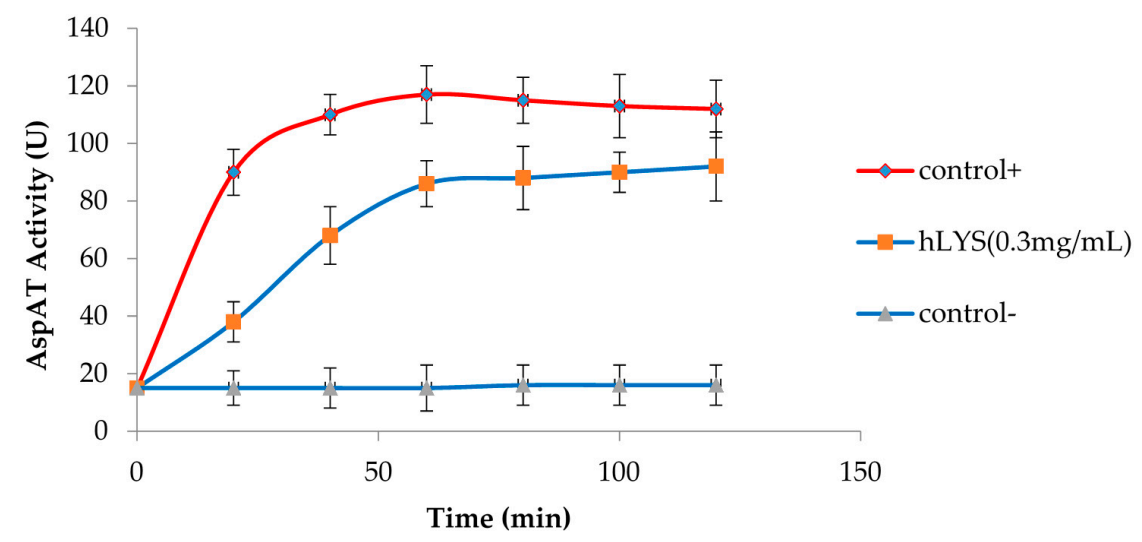

Figure 3. Increased AspAT activity resulting from the release of AspAT from H. pylori treated with hLYS. Triton $(0.2 \%)$ was used as a positive control; $0.9 \% \mathrm{NaCl}$ solution was used as a negative control.

\section{4. hLYS Could Promote PI Uptake by Cells}

To further clarify whether hLYS could promote cell absorption of external substances under conditions of increasing penetration of the outer membrane and disrupting the integrity of the inner membrane, we used a visual method. PI was absorbed into cells and bound to DNA, resulting in the emission of red fluorescence that could be easily detected using fluorescence confocal microscopy [26]. As shown in Figure 4, this experiment demonstrated that hLYS could promote PI uptake into cells, which could be visualized. If lysozyme could promote PI absorption, this effect would also promote the absorption of metronidazole into cells by increasing membrane permeability caused by membrane damage induced by hLYS. The concentration of metronidazole in the cells could be increased, resulting in enhanced antimicrobial activity.
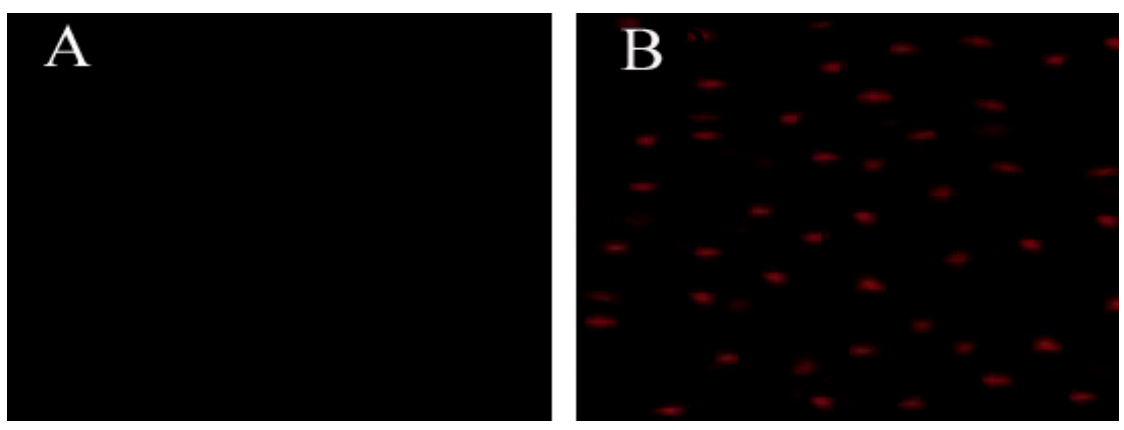

Figure 4. Effect of hLYS on H. pylori membrane permeabilization. H. pylori was incubated with (A) PBS (a control) or (B) $50 \mu \mathrm{M}$ PI and $0.3 \mathrm{mg} / \mathrm{mL}$ hLYS for $90 \mathrm{~min}$ at room temperature under microaerophilic conditions. The cells were observed using fluorescence confocal microscopy. (A) No fluorescence was observed, indicating that PI could not enter the cells; (B) A few red fluorescence dots could be observed, demonstrating that PI could enter cells and bind to DNA. 


\subsection{Bactericidal Kinetics of hLYS and Metronidazole Treatment}

H. pylori cells are highly resistant to the bactericidal effects of lysozyme, as they can survive for hours in up to $30 \mathrm{mg} / \mathrm{mL}$ (our study) or $50 \mathrm{mg} / \mathrm{mL}$ (another study [27]) lysozyme, which indicated that oral lysozyme alone may not achieve the maximal effect of killing $H$. pylori, but $0.3 \mathrm{mg} / \mathrm{mL}$ hLYS can enhance cell membrane permeability. The bactericidal activity kinetics against $H$. pylori ATCC 43504 were investigated by counting the number of surviving bacteria according to a previously reported method [27]. Cell survival was measured within the first $60 \mathrm{~min}$ after bacterial exposure to different concentrations of metronidazole or to metronidazole along with $0.3 \mathrm{mg} / \mathrm{mL} \mathrm{hLYS}$ at different time points. As shown in Figure 5, $0.3 \mathrm{mg} / \mathrm{mL}$ hLYS synergized with metronidazole to kill $H$. pylori. Furthermore, regarding the bactericidal kinetics, the concentration of metronidazole become markedly lower and bactericidal time become shorter, so while metronidazole cannot completely kill $\mathrm{H}$. pylori within 60 min at a concentration of $4 \times$ MIC, it could completely kill H. pylori within 20 min at a concentration of $4 \times$ MIC.

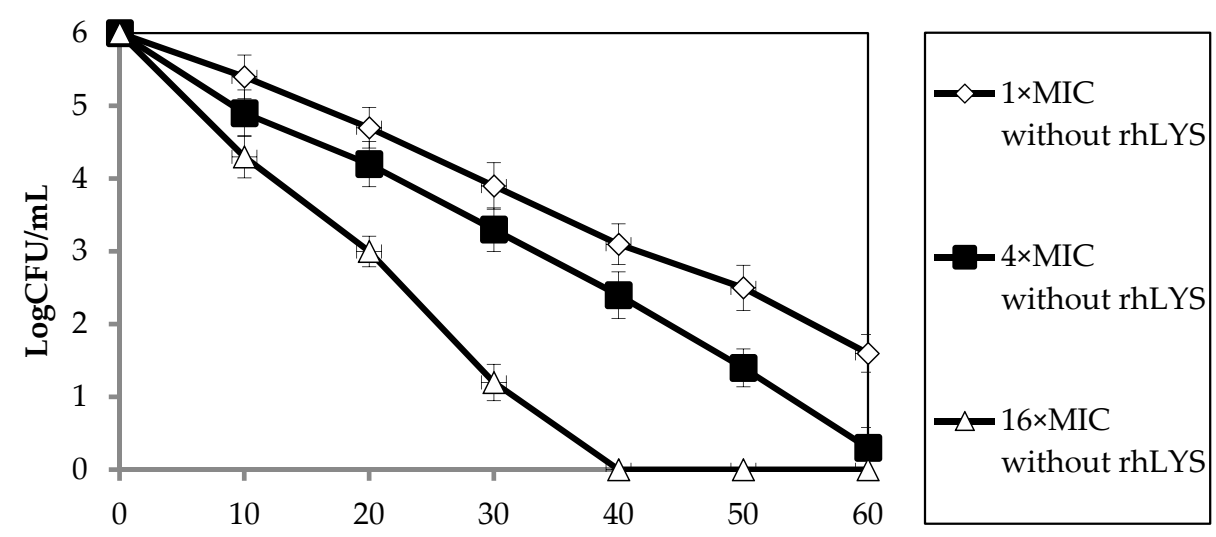

A

Exposure time(min)

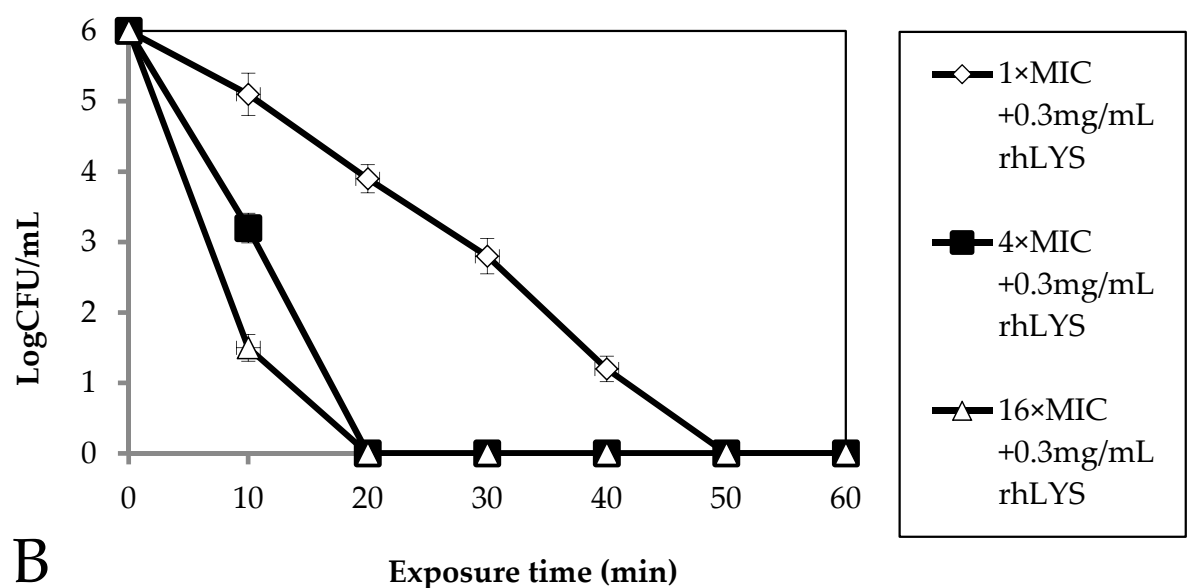

Figure 5. Bactericidal kinetics. The bactericidal kinetics of metronidazole without hLYS (A) and of metronidazole with $0.3 \mathrm{mg} / \mathrm{mL}$ hLYS (B) against H. pylori were monitored at $10 \mathrm{~min}$ intervals for $1 \mathrm{~h}$ at $37^{\circ} \mathrm{C}$. Subsequently, aliquots were diluted (serial 10-fold dilutions) and plated for CFU counts after $72 \mathrm{~h}$ incubation at $37^{\circ} \mathrm{C}$.

\subsection{Effect of hLYS on the MPC and MIC of Metronidazole to H. pylori}

We found that hLYS could significantly reduce the MIC and MPC of metronidazole on H. pylori using an agar dilution method (Table 2). The MIC and MPC of metronidazole in H. pylori changed from 8 and $153.6 \mu \mathrm{g} / \mathrm{mL}$ to 1 and $25.6 \mu \mathrm{g} / \mathrm{mL}$, respectively. The MSW of metronidazole in $H$. pylori 
narrowed from 145.6 to $24.6 \mu \mathrm{g} / \mathrm{mL}$. Considering the theoretical basis of the MSW, this effect should reduce the probability of mutations arising that render $H$. pylori resistant to antibiotics.

Table 2. Effect of hLYS $(0.3 \mathrm{mg} / \mathrm{mL})$ on the MIC, MPC and MSW of MNZ to H. pylori.

\begin{tabular}{cccc}
\hline Formulation & MIC & MPC & MSW \\
\hline MNZ & $8 \mu \mathrm{g} / \mathrm{mL}$ & $153.6 \mu \mathrm{g} / \mathrm{mL}$ & $145.6 \mu \mathrm{g} / \mathrm{mL}$ \\
MNZ + hLYS & $1 \mu \mathrm{g} / \mathrm{mL}^{*}$ & $25.6 \mu \mathrm{g} / \mathrm{mL}^{* *}$ & $24.6 \mu \mathrm{g} / \mathrm{mL}{ }^{* *}$ \\
\hline${ }^{* *} p<0.01$ compared with MNZ; ${ }^{*} p<0.05$ compared with MNZ.
\end{tabular}

\section{Discussion}

It has been reported that resistance to MNZ accounts for a reduction in efficacy of up to $50 \%$ for bismuth- and PPI-containing triple therapies [11]. Recently, studies have shown that $H$. pylori resistance to MNZ reaches $17 \%-44 \%$ in Europe and America, while the highest resistance rates have been estimated to be $80 \%-92.4 \%$ in Africa $[28,29]$. In the last decade, the rate of $H$. pylori resistance to MNZ has significantly increased in China from $23.8 \%$ to $56.6 \%$ [30]. To achieve the therapeutic effect of $H$. pylori resistance to MNZ, some improved therapeutic methods have been achieved by increasing the MNZ dose (1600 mg/day or even $2 \mathrm{~g} /$ day) and prolonging the duration of therapy (from the original 7 days to the present 10 or 14 days) [12,31-33]. Although these methods have achieved a certain therapeutic effect, according to the MSW theory, the status of $H$. pylori resistance to MNZ will worsen using the above treatment strategy because the concentration of MNZ is between the MIC and MPC, and a prolonged treatment time can enrich and promote $H$. pylori resistance mutations to $\mathrm{MNZ}$ [13-16]. If the concentrations of $\mathrm{MNZ}$ are above the MPC, H. pylori resistance mutations rarely emerge, but an MNZ concentration that remains above the MPC in the stomach is difficult to achieve because of the stomach emptying. MNZ resistance have been reported to be associated with mutations of oxygen independent NADPH nitroreductase (RdxA) and NADH flavin oxidoreductase (FrxA) [34,35]. The study confirmed that the sensitive strain of MNZ become resistant strains due to $\operatorname{rdxA}$ and frxA gene mutation using natural transformation experiments through the selection of low concentration of MNZ [36]. Therefore, a method of lowering the MPC, narrowing MSW and enhancing the bactericidal dynamics, i.e., to shorten the bacterial killing time, must be found to block the resistance mutations induced by MNZ and enhance its bactericidal effects. In this study, a method to increase the permeability of $H$. pylori was used that would be beneficial for MNZ via effects on the bacterial cell wall and cell membrane, which could lower the MPC of MNZ and result in more rapid killing of H. pylori. Although MNZ only remained for a short time in the stomach, a more effective inhibition and killing of $H$. pylori could be achieved, and the bacteria would be less likely to develop drug resistance to MNZ. Previous studies established that $H$. pylori has a high tolerance to lysozyme, as H. pylori could not be completely killed at a concentration of $50 \mathrm{mg} / \mathrm{mL}$ [23]. Indeed, in this study, we found that $H$. pylori could not be completely killed by $30 \mathrm{mg} / \mathrm{mL}$ hLYS for $6 \mathrm{~h}$, while $0.3 \mathrm{mg} / \mathrm{mL}$ hLYS demonstrated weaker activity towards $H$. pylori, as many H. pylori survived after hLYS acted on the bacteria for $6 \mathrm{~h}$. Therefore, a complete cure of $H$. pylori infection could not be attained by direct oral administration of lysozyme. However, lysozyme can act on the bacterial cell wall peptidoglycans $\beta$-1,4-linked $N$-acetylmuramic acid (MurNAc) and $N$-acetylglucosamine (GlucNAc), and it has the characteristic of a cation, which can increase cell permeability, which is beneficial for antibiotic entry into the cell and can enhance antibacterial activity. In the present study, we found that $0.3 \mathrm{mg} / \mathrm{mL}$ recombinant human lysozyme increased the permeability of the cell wall and destroyed the integrity of the cell membrane of H. pylori (Figures 1 and 2). Additionally, it also enhanced the absorption of outside material into cells (Figure 3). We carried out further assessments and found that $0.3 \mathrm{mg} / \mathrm{mL}$ hLYS was synergistic with MNZ against H. pylori; it increased the MNZ bactericidal kinetics for a given concentration, lowering the bactericidal time. Thus, the conditions changed from the original observation that MNZ could not completely kill H. pylori at a concentration of $4 \times$ MIC in $60 \mathrm{~min}$, to a 
state where it could completely kill $H$. pylori at a concentration of $4 \times \mathrm{MIC}$ in 20 min (Figure 5). We also found that $0.3 \mathrm{mg} / \mathrm{mL}$ hLYS could significantly reduce the MPC of MNZ (Table 2). Our findings indicated that a concentration above the MPC could easily be reached in the stomach using the original oral dose for MNZ and hLYS to treat $H$. pylori infection. This treatment would not only enhance the treatment effects of MNZ but also greatly reduce the resistance of $H$. pylori to MNZ. This study may provide a new technique to solve the problem of antibiotic resistance for the treatment of bacterial infections in the clinic.

\section{Materials and Methods}

\subsection{Bacterial Strain and Chemicals}

The bacterial strain ATCC43504 of H. pylori was used in this study and was maintained in our laboratory. hLYS was purchased from Prospec-Tany TechnoGene. Ltd. (Rehovot, Israel). The compounds metronidazole, $N$-2-hydroxyethylpiperazine- $N^{\prime}$-2-ethanesulfonic acid (HEPES), malate dehydrogenase (MDH), pyridoxal-5' -phosphate L-aspartate, NADH, $\alpha$-ketoglutarate, NPN and propidium iodide (PI) were purchased from Sigma Chemical Co. (St. Louis, MO, USA).

\subsection{Culture Conditions for H. pylori}

H. pylori was cultured on Columbia blood agar plates (CM0331B; Oxoid, Basingstoke, UK) supplemented with $10 \%$ defibrinated sheep blood. Plates were incubated at $37{ }^{\circ} \mathrm{C}$ for 3 days in microaerophilic atmospheric conditions that were established using a microaerophilic gas-generating bag (QingDao Hope Bio-Technology Co., Ltd., QingDao, China).

\subsection{Cell Survival Assays to Determine hLYS Sensitivity}

H. pylori strains were grown on Columbia blood agar plates supplemented with $10 \%$ defibered sheep blood for $24 \mathrm{~h}$ until they reached log phase. The cells were centrifuged at $5000 \times g$ for $10 \mathrm{~min}$, and then, the cells were suspended in phosphate-buffered saline (PBS) and adjusted to a concentration of $10^{8} \mathrm{CFU} / \mathrm{mL}$. A final concentration of 0.3 or $30 \mathrm{mg} / \mathrm{mL}$ of lysozyme was added to a final $7.5 \times 10^{7} \mathrm{CFU} / \mathrm{mL}$ of $H$. pylori with full mixing. The cell suspensions were incubated at $37^{\circ} \mathrm{C}$ under microaerophilic atmosphere conditions with shaking at $200 \mathrm{rpm}$. Samples were then harvested at various time points $(0,2,4$, and $6 \mathrm{~h})$, and plated onto Columbia blood agar plates after serial dilution. Colony counts were carried out after 3 days of incubation in a microaerobic atmosphere at $37^{\circ} \mathrm{C}$.

\subsection{Permeabilization Assay of the Outer Membrane (OM)}

The effect of $H$. pylori OM permeabilization on hLYS was determined using a fluorescent probe of hydrophobic NPN [24,25]. A $50 \mathrm{~mL}$ sample of log phase H. pylori was centrifuged at $5000 \times g$ for $10 \mathrm{~min}$. Cells were collected, washed three times, and suspended in $5 \mathrm{mM}$ sodium HEPES buffer ( $\mathrm{pH}$ 7.2). Then, the optical density at $600 \mathrm{~nm}$ was adjusted to 0.5. Samples (4 mL) containing $2 \mathrm{~mL}$ H. pylori suspension, $1 \mathrm{~mL}$ hLYS at $0.1,0.2,0.3,0.4$, or $0.5 \mathrm{mg} / \mathrm{mL}$ and $1 \mathrm{~mL}$ of $40 \mathrm{mM}$ NPN were prepared. The control was $2 \mathrm{~mL}$ of $5 \mathrm{mM}$ HEPES without cells. Excitation and emission wavelengths for NPN were set at 350 and $420 \mathrm{~nm}$, respectively. Increases in fluorescent intensity resulting from NPN penetrating into the OM were measured at $30 \mathrm{~s}$ intervals until no further increase was observed (F4600 fluorescence spectrophotometer, Hitachi, Tokyo, Japan). The experiments were carried out three times to obtain the average value.

\subsection{Integrity Assay of the Inner Membrane (IM)}

The effect of hLYS on H. pylori IM integrity was determined by measuring the release of aspartate aminotransferase (AspAT) from H. pylori into the culture medium. AspAT activity was indicated by the amount of aspartate converted to oxaloacetate by measuring the malate dehydrogenase $(\mathrm{MDH})$-catalyzed, NADH-dependent conversion of oxaloacetate to malate. The enzymatic activity 
of AspAT was detected by the reduction in absorbance at $340 \mathrm{~nm}$. A $50 \mathrm{~mL}$ sample of log phase H. pylori was centrifuged at $5000 \times g$ for $10 \mathrm{~min}$. The cells were collected, washed three times, and suspended in a $0.9 \% \mathrm{NaCl}$ solution, after which the optical density at $600 \mathrm{~nm}$ was adjusted to 1.0 in accordance with a previously reported method with slight modifications [37]. The AspAT reaction mixture $(4 \mathrm{~mL})$ contained $2 \mathrm{~mL} \mathrm{H}$. pylori suspension, $1 \mathrm{~mL}$ hLYS at $0.3 \mathrm{mg} / \mathrm{mL}, 20 \mathrm{mM}$ Tris (pH 7.8), $50 \mu \mathrm{M}$ pyridoxal-5'-phosphate, $20 \mathrm{mM} \alpha$-ketoglutarate, $50 \mathrm{mM}$ L-aspartate, $0.2 \mathrm{mM}$ $\mathrm{NADH}$, and 12U MDH. Positive and negative controls were $0.2 \%$ Triton and $0.9 \% \mathrm{NaCl}$, respectively. An increase in AspAT activity was represented by the reduction in absorbance at $340 \mathrm{~nm}$ using a spectrophotometer. One unit of AspAT was defined as the amount of enzyme that catalyzed the oxidation of $1 \mu \mathrm{mol} \mathrm{NADH} \mathrm{min}^{-1}$ and led to a reduction in absorbance of $0.001 \mathrm{~min}^{-1}$. AspAT activity was measured at $20 \mathrm{~min}$ intervals until no further increase resulting from the increasing penetration of AspAT from cells by hLYS was detected. The experiments were carried out three times to obtain the average value.

\subsection{Cell Uptake Assay}

A mixture of $1 \mathrm{~mL}$ of $H$. pylori suspension (optical density 0.5 at $600 \mathrm{~nm}$ ) and $1 \mathrm{~mL}$ of $30 \mathrm{mg} / \mathrm{mL}$ hLYS or $1 \mathrm{~mL}$ of PBS buffer ( $\mathrm{pH}=7.2$, as a control) were incubated for $2 \mathrm{~h}$ at $37^{\circ} \mathrm{C}$, then $2 \mathrm{~mL}$ of $100 \mu \mathrm{M}$ propidium iodide (PI) was added. The mixture was further incubated for $5 \mathrm{~min}$ at room temperature in the dark. PI entered the cell, bound to DNA and emitted red fluorescence only under conditions that caused damage to the cell membrane. Red fluorescence could be detected with a fluorescence confocal microscope (LSM 710 Meta, Zeiss, Jene, Gemany). The experiments were carried out three times to obtain the average value.

\subsection{Bactericidal Kinetics Activity Based on hLYS and Metronidazole Synergy}

The MIC was tested using a standard serial dilution method that was previously described by our group [27]. Briefly, H. pylori was cultured overnight in BHI broth under microaerophilic conditions at $37^{\circ} \mathrm{C}$, and then the mixture was centrifuged to collect the bacterial pellet at $5000 \times g$ for $10 \mathrm{~min}$. The pellet was properly diluted and its optical density at $600 \mathrm{~nm}\left(\mathrm{OD}_{600}\right)$ was adjusted to 1.0 . The number of $H$. pylori cells corresponded to approximately $1 \times 10^{8}$ colony forming units $(\mathrm{CFU}) / \mathrm{mL}$. MNZ was serially diluted, and the concentration range of MNZ was 1 to $512 \mu \mathrm{g} / \mathrm{mL}$. Additionally, $10 \mu \mathrm{L}$ of bacterial suspension containing $1 \times 10^{6} \mathrm{CFU}$ of bacteria was added to each $1 \mathrm{~mL}$ serial diluted solution. After $36 \mathrm{~h}$ of culture with shaking at $200 \mathrm{rpm}$ under microaerobic conditions at $37^{\circ} \mathrm{C}$, the MIC was taken as the lowest drug concentration at which the tube was optically clear without any visible turbidity or growth. The experiments described above were conducted in triplicate. The bactericidal kinetics assay of hLYS plus MNZ against $H$. pylori was carried out as our group reported previously with some modifications [27]. Aliquots $(1 \mathrm{~mL})$ of different concentrations of MNZ culture media were prepared to obtain final concentrations of $1 \times \mathrm{MIC}, 4 \times \mathrm{MIC}$, or $16 \times \mathrm{MIC}$ containing $10^{6} \mathrm{CFU} / \mathrm{mL}$ H. pylori (at the exponential phase of growth) and $0.3 \mathrm{mg} / \mathrm{mL}$ hLYS; the control had no hLYS. After 0 , $10,20,30,40,50$ and $60 \mathrm{~min}$ of incubation under microaerophilic conditions at $37^{\circ} \mathrm{C}$, the cultures were serially diluted by adding $20 \mu \mathrm{L}$ of culture to $180 \mu \mathrm{L}$ of BHI broth. The samples were fully mixed and $50 \mu \mathrm{L}$ of each dilution was plated on Columbia blood agar (CM0331B, Oxoid) supplemented with 7\% defibered sheep blood for CFU counts after $48 \mathrm{~h}$ of incubation under microaerophilic conditions at $37^{\circ} \mathrm{C}$. The above experiments were conducted in triplicate.

\subsection{Measurement of MPC}

MPC measurements were performed as previously described with some modifications [38,39]. Briefly, H. pylori was cultured in BHI broth containing 7\% fetal bovine serum and incubated for $24 \mathrm{~h}$. Cultures were centrifuged at $5000 \times g$ for $10 \mathrm{~min}$ and resuspended in BHI broth to obtain a concentration of $10^{11} \mathrm{CFU} / \mathrm{mL}$. A series of Columbia blood agar plates supplemented with $7 \%$ defibered sheep blood, various known MNZ concentrations and $0.3 \mathrm{mg} / \mathrm{mL}$ hLYS were plated with $100 \mu \mathrm{L}$ of a suspension 
containing $10^{10} \mathrm{CFU}$ of $H$. pylori and compared with MNZ alone. The inoculated plates were incubated for $72 \mathrm{~h}$ under microaerophilic conditions at $37^{\circ} \mathrm{C}$ and screened visually to count the CFU. The lowest concentration of drug without visual colony growth was set as a provisional mutation prevention concentration (MPCpr) after culture for $72 \mathrm{~h}$. After repeating the above operation, MPCpr was set as the baseline with a $20 \%$ linear decreasing concentration of antibiotic, and agar plates containing different concentrations of drug were prepared. The MPC was defined as the lowest concentration of drug that still did not support visual colony growth after $72 \mathrm{~h}$ of culture. The experiments were carried out three times.

\subsection{Statistical Analysis}

The difference was statistically analyzed between the MNZ-treated bacterial samples and MNZ + hLYS-treated bacterial samples were statistically analyzed using one-way analysis variance and Dunnett's multiple comparison test. The significant differences between different bacterial samples were defined as $p<0.05$.

\section{Conclusions}

MNZ is an effective agent used to eradicate $H$. pylori. The emergence of widespread H. pylori resistance to $\mathrm{MNZ}$ has affected its therapeutic effects. Effective treatments to overcome MNZ resistance can be obtained by increasing the MNZ dose and prolonging the duration of therapy. According to the MSW theory, resistant mutants would thus be selected or enriched. A strategy to enhance the bactericidal dynamics and lower the resistant mutant prevention concentration would overcome this problem. hLYS possesses muramidase activity that can catalyze the hydrolysis of bacterial cell wall peptidoglycans, including $\beta$-1,4-linked $N$-acetylmuramic acid (MurNAc) and $N$-acetylglucosamine (GlucNAc). Additionally, hLYS can also act in a cationic-dependent mode. These effects can increase the permeability of bacterial cells. In this study, our findings demonstrated that hLYS indeed could promote increased penetration of the outer membrane, cause disruption of the integrity of the inner membrane, and promote the uptake of extracellular substances into cells. Further studies found that the bactericidal activity kinetics of MNZ were markedly enhanced from the original in which MNZ could not completely kill $H$. pylori at a concentration of $4 \times \mathrm{MIC}$ in $60 \mathrm{~min}$ to a state where it could completely kill $H$. pylori at a concentration of $4 \times \mathrm{MIC}$ in $20 \mathrm{~min}$. The MIC and MPC for MNZ in H. pylori were obviously reduced from 8 and $153.6 \mu \mathrm{g} / \mathrm{mL}$ to 4 and $25.6 \mu \mathrm{g} / \mathrm{mL}$, respectively. The MSW was significantly narrowed from 145.6 to $21.6 \mu \mathrm{g} / \mathrm{mL}$. These findings demonstrated that hLYS with MNZ produced a very low MIC, rapidly killed bacteria, and had a low propensity for generating resistance because of the narrow MSW. In conclusion, the present study establishes that hLYS acts in combination with MNZ to eradicate H. pylori infections and reduce the rate of resistance mutations by increasing cell permeability.

Acknowledgments: This work was supported by research grants from the Natural Science Foundation of Anhui Province Education Department (No. KJ2016SD16).

Author Contributions: Xiaolin Zhang, Anmin Jiang and Jianfei Wang designed the study; Hao Yu, Guoliang Zhou performed the permeabilization assay of the outer membrane and integrity assay of the inner membrane studies, Meisong Qin, Jinfeng Dou performed the cell uptake assay, Youyi Xiong performed the culture of H. pylori and cell survival assays to determine hLYS sensitivity, Xiaolin Zhang performed the bactericidal kinetics activity based on hLYS and metronidazole synergy and measurement of MPC studies. All authors analyzed the data and wrote the article.

Conflicts of Interest: The authors declare no conflict of interest.

\section{References}

1. Moayyedi, P.; Hunt, R.H. Helicobacter pylori public health implications. Helicobacter 2004, 9, 67-72. [CrossRef] [PubMed]

2. Malfertheiner, P.; Chan, F.K.; McColl, K.E. Peptic ulcer disease. Lancet 2009, 374, 1449-1461. [CrossRef] 
3. Kuipers, E.J. H. pylori and the risk and management of associated diseases: Gastritis, ulcer disease, atrophic gastritis and gastric cancer. Aliment. Pharmacol. Ther. 1997, 11, 71-88. [CrossRef] [PubMed]

4. Wang, J.; Chen, R.C.; Zheng, Y.X.; Zhao, S.S.; Li, N.; Zhou, R.R.; Huang, Y.; Huang, Z.B.; Fan, X.G. Helicobacter pylori infection may increase the risk of progression of chronic hepatitis B disease among the Chinese population: A meta-analysis. Int. J. Infect. Dis. 2016, 50, 30-37. [CrossRef] [PubMed]

5. Zhao, B.; Zhao, J.; Cheng, W.F.; Shi, W.J.; Liu, W.; Pan, X.L.; Zhang, G.X. Efficacy of H. pylori eradication therapy on functional dyspepsia: A meta-analysis of randomized controlled studies with 12-month follow-up. J. Clin. Gastroenterol. 2014, 48, 241-247. [CrossRef] [PubMed]

6. Guo, Q.; Guo, S.; Zhang, Y. Treatment of gastric MALT lymphoma with a focus on H. pylori eradication. Int. J. Hematol. 2013, 97, 735-742. [CrossRef] [PubMed]

7. Shiotani, A.; Cen, P.; Graham, D.Y. Eradication of gastric cancer is now both possible and practical. Semin. Cancer Biol. 2013, 23, 492-501. [CrossRef] [PubMed]

8. Malfertheiner, P.; Megraud, F.; O’Morain, C.A.; Atherton, J.; Axon, A.T.; Bazzoli, F.; Gensini, G.F.; Gisbert, J.P.; Graham, D.Y.; Rokkas, T.; et al. Management of H. pylori infection-the Maastricht IV/Florence Consensus Report. Gut 2012, 61, 646-664. [CrossRef] [PubMed]

9. Banić, M.; Franceschi, F.; Babić, Z.; Gasbarrini, A. Extragastric manifestations of H. pylori infection. Helicobacter 2012, 17, 49-55.

10. Georgopoulos, S.D.; Polymeros, D.; Triantafyllou, K.; Spiliadi, C.; Mentis, A.; Karamanolis, D.G.; Ladas, S.D. Hypergastrinemia is associated with increased risk of distal colon adenomas. Digestion 2006, 74, 42-46. [CrossRef] [PubMed]

11. Houben, M.H.; van de Beek, D.; Hensen, E.F.; de Craen, A.J.; Rauws, E.A.; Tytgat, G.N. A systematic review of $H$. pylori eradication therapy-the impact of antimicrobial resistance on eradication rates. Aliment. Pharmacol. Ther. 1999, 13, 1047-1055. [CrossRef] [PubMed]

12. Graham, D.Y.; Qureshi, W.A. Antibiotic-resistant H. pylori infection and its treatment. Curr. Pharm. Des. 2000, 6, 1537-1544. [PubMed]

13. Zhao, X.; Drlica, K. Restricting the selection of antibiotic-resistant mutants: A general strategy derived from fluoroquinolone studies. Clin. Infect. Dis. 2001, 33, S147-S156. [CrossRef] [PubMed]

14. Olofsson, S.K.; Cars, O. Optimizing drug exposure to minimize selection of antibiotic resistance. Clin. Infect. Dis. 2007, 45, S129-S136. [CrossRef] [PubMed]

15. Drlica, K. The mutant selection window and antimicrobial resistance. J. Antimicrob. Chemother. 2003, 52, 11-17. [CrossRef] [PubMed]

16. Drlica, K.; Zhao, X. Mutant selection window hypothesis updated. Clin. Infect. Dis. 2007, 44, 681-688. [CrossRef] [PubMed]

17. Akinbi, H.T.; Epaud, R.; Bhatt, H.; Weaver, T.E. Bacterial killing is enhanced by expression of lysozyme in the lungs of transgenic mice. J. Immunol. 2000, 165, 5760-5766. [CrossRef] [PubMed]

18. Markart, P.; Korfhagen, T.R.; Weaver, T.E.; Akinbi, H.T. Mouse lysozyme M is important in pulmonary host defense against Klebsiella pneumoniae infection. Am. J. Respir. Crit. Care Med. 2004, 169, 454-458. [CrossRef] [PubMed]

19. Martinez, J.G.; Waldon, M.; Huang, Q.; Alvarez, S.; Oren, A.; Sandoval, N.; Du, M.; Zhou, F.; Zenz, A.; Lohner, K.; et al. Membrane-targeted synergistic activity of docosahexaenoic acid and lysozyme against Pseudomonas aeruginosa. Biochem. J. 2009, 419, 193-200. [CrossRef] [PubMed]

20. Koch, A.L. Bacterial wall as target for attack: Past, present, and future research. Clin. Microbiol. Rev. 2003, 16, 673-687. [CrossRef] [PubMed]

21. Ibrahim, H.R.; Matsuzaki, T.; Aoki, T. Genetic evidence that antibacterial activity of lysozyme is independent of its catalytic function. FEBS Lett. 2001, 506, 27-32. [CrossRef]

22. Nash, J.A.; Ballard, T.N.; Weaver, T.E.; Akinbi, H.T. The peptidoglycan degrading property of lysozyme is not required for bactericidal activity in vivo. J. Immunol. 2006, 177, 519-526. [CrossRef] [PubMed]

23. Wang, G.; Lo, L.F.; Forsberg, L.S.; Maier, R.J. Helicobacter pylori peptidoglycan modifications confer lysozyme resistance and contribute to survival in the host. MBio 2012, 3, e00409-12. [CrossRef] [PubMed]

24. Helander, I.M.; Mattila-Sandholm, T. Fluorometric assessment of gram-negative bacterial permeabilization. J. Appl. Microbiol. 2000, 88, 213-219. [CrossRef] [PubMed] 
25. Loh, B.; Grant, C.; Hancock, R.E. Use of the fluorescent probe 1-N-Phenylnaphthyl-amine to study the interactions of aminoglycoside antibiotics with the outer membrane of pseudomonas aeruginosa. Antimicrob. Agents Chemother. 1984, 26, 546-551. [CrossRef] [PubMed]

26. Nicoletti, I.; Migliorati, G.; Pagliacci, M.C.; Grignani, F.; Riccardi, C. A rapid and simple method for measuring thymocyte apoptosis by propidium iodide staining and flow cytometry. J. Immunol. Methods 1991, 139, 271-279. [CrossRef]

27. Zhang, X.L.; Jiang, A.M.; Ma, Z.Y.; Li, X.B.; Xiong, Y.Y.; Dou, J.F.; Wang, J.F. The synthetic antimicrobial peptide Pexiganan and its nanoparticles (PNPs) exhibit the anti-H. pylori activity in vitro and in vivo. Molecules 2015, 20, 3972-3985. [CrossRef] [PubMed]

28. De Francesco, V.; Giorgio, F.; Hassan, C.; Manes, G.; Vannella, L.; Panella, C.; Ierardi, E.; Zullo, A. Worldwide H. pylori antibiotic resistance: A systematic review. J. Gastrointest. Liver Dis. 2010, 19, 409-414.

29. Mégraud, F. H. pylori antibiotic resistance: Prevalence, importance, and advances in testing. Gut 2004, 53, 1374-1384.

30. Gao, W.; Cheng, H.; Hu, F.; Li, J.; Wang, L.; Yang, G.; Xu, L.; Zheng, X. The evolution of H. pylori antibiotics resistance over 10 years in Beijing, China. Helicobacter 2010, 15, 460-466. [CrossRef] [PubMed]

31. Borody, T.J.; Carrick, J.; Hazell, S.L. Symptoms improve after the eradication of gastric Campylobacter pyloridis. Med. J. Aust. 1987, 146, 450-451. [PubMed]

32. Kuo, C.H.; Hsu, P.I.; Kuo, F.C.; Wang, S.S.; Hu, H.M.; Liu, C.J.; Chuah, S.K.; Chen, Y.H.; Hsieh, M.C.; $\mathrm{Wu}$, D.C.; et al. Comparison of 10 day bismuth quadruple therapy with high-dose metronidazole or levofloxacin for second-line H. pylori therapy: A randomized controlled trial. J. Antimicrob. Chemother. 2013, 68, 222-228. [CrossRef] [PubMed]

33. Liang, X.; Xu, X.; Zheng, Q.; Zhang, W.; Sun, Q.; Liu, W.; Xiao, S.; Lu, H. Efficacy of bismuth-containing quadruple therapies for clarithromycin-, metronidazole-, and fluoroquinolone-resistant $H$. pylori infections in a prospective study. Clin. Gastroenterol. Hepatol. 2013, 11, 802-807. [CrossRef] [PubMed]

34. Jeong, J.Y.; Mukhopadhyay, A.K.; Dailidiene, D.; Wang, Y.; Velapatiño, B.; Gilman, R.H.; Parkinson, A.J.; Nair, G.B.; Wong, B.C.; Lam, S.K.; et al. Sequential inactivation of $r d x A$ (HP0954) and frxA (HP0642) nitroreductase genes causes moderate and high-level metronidazole resistance in Helicobacter pylori. J. Bacteriol. 2000, 182, 5082-5090. [CrossRef] [PubMed]

35. Goodwin, A.; Kersulyte, D.; Sisson, G.; Veldhuyzen van Zanten, S.J.O.; Berg, D.E.; Hoffman, P.S. Metronidazole resistance in Helicobacter pylori is due to null mutations in a gene $(r d x A)$ that encodes an oxygen-insensitive NADPH nitroreductase. Mol. Microbiol. 1998, 28, 383-393. [CrossRef] [PubMed]

36. Binh, T.T.; Suzuki, R.; Trang, T.T.; Kwon, D.H.; Yamaoka, Y. Search for novel candidate mutations for metronidazole resistance in Helicobacter pylori using next-generation sequencing. Antimicrob. Agents Chemother. 2015, 59, 2343-2348. [CrossRef] [PubMed]

37. Ward, D.E.; de Vos, W.M.; van der Oost, J. Molecular analysis of the role of two aromatic aminotrans-ferases and a broad-specificity aspartate aminotransferase in the aromatic amino acid metabolism of Pyrococcus furiosus. Archaea 2002, 1, 133-141. [CrossRef] [PubMed]

38. Zhao, X.; Drlica, K. Restricting the selection of antibiotic-resistant mutant bacteria: Measurement and potential use of the mutant selection window. J. Infect. Dis. 2002, 185, 561-565. [CrossRef] [PubMed]

39. Blondeau, J.M.; Zhao, X.; Hansen, G.; Drlica, K. Mutant prevention concentration of fluoroquinolones for clinical isolates of Streptococcus pneumoniae. Antimicrob. Agents Chemother. 2001, 45, 433-438. [CrossRef] [PubMed]

Sample Availability: Samples of the compounds metronidazole, human lysozyme, 1-N-phenylnaphthylamine (NPN), propidium iodide(PI), N-2-hydroxyethylpiperazine- $N^{\prime}$-2-ethanesulfonic acid (HEPES), malate dehydrogenase $(\mathrm{MDH})$, pyridoxal-5'-phosphate L-aspartate, $\mathrm{NADH}, \alpha$-ketoglutarate are available from the authors. 